\title{
Response of Growing Dairy Bulls to Dietary Tannin in Rations with Varying Energy Levels
}

\author{
J. B. Poblete ${ }^{\mathrm{a}, *}$, A. A. Angeles ${ }^{\mathrm{b}}$, E. M. Agbisit, Jr. ${ }^{a}$, \& M. V. O. Espaldon ${ }^{\mathrm{c}}$ \\ anstitute of Animal Science, College of Agriculture and Food Sciences, University of the Philippines \\ ${ }^{b}$ Dairy Training and Research Institute, College of Agriculture and Food Sciences, University of the Philippines \\ 'School of Environmental Science and Management, University of the Philippines \\ Los Baños, College, Laguna 4031 \\ ${ }^{*}$ Corresponding author: pobletejoe17@gmail.com \\ (Received 09-07-2019; Revised 29-08-2019; Accepted 20-09-2019)
}

\begin{abstract}
This study was conducted to determine the effect of dietary tannin on growth performance, rumen fluid characteristics, and apparent total-tract digestibility in growing Holstein-Friesian $x$ Sahiwal bulls fed low and high energy rations. Eighteen growing bulls with initial body weight (BW) of $162.8 \pm 12.7 \mathrm{~kg}$ at $15 \pm 0.80$ months were used in an unbalanced randomized complete block design set-up in a $2 \times 2$ factorial arrangement. The experimental animals were blocked by their respective BW. Animals were fed with concentrates containing metabolizable energy (ME) at 2.47 and 2.72 $\mathrm{Mcal} / \mathrm{kg}$ without or with $20 \mathrm{~g} / \mathrm{kg}$ tannin in dry matter basis. At the final week of the trial, rumen fluid and fecal samples were collected for the rumen fluid characteristics and apparent total-tract digestibility analyses. No differences $(p>0.05)$ were observed between the growth performance, rumen gas production, volatile fatty acids as well as organic matter, crude protein, and energy digestibility. High energy concentrates had higher $(\mathrm{p}<0.05)$ dry matter and neutral detergent fiber digestibility than low energy concentrates. Low energy concentrates without tannin had cheaper $(p<0.001)$ total feed cost but feed cost per kilogram BW gain was similar $(p>0.05)$ across treatments. Feed savings costs of US\$ 17.58 per animal were attained in feeding low energy concentrates without tannin. Therefore, feeding concentrates containing $2.47 \mathrm{Mcal} / \mathrm{kg}$ ME without additional tannin can still be fed economically to growing cattle without any adverse effect on growth, ruminal fermentation characteristics, and apparent total-tract digestibility.
\end{abstract}

Keywords: tannin; metabolizable energy; apparent total-tract digestibility; in vitro gas production

\section{INTRODUCTION}

The cattle industry is currently being threatened by the decline in pasture and forage availability, climate change, and economic disadvantages among the other factors. The conversion of pasture and agricultural lands to residential and industrial areas and the increasing demand for meat and milk are directly related to the growth of the human population. Furthermore, cattle production also significantly contributes to greenhouse gases that warm the atmosphere. According to FAO (2017), cattle accounted for 62 percent of the total livestock emissions which was equal to 5.0 gigatonnes $\mathrm{CO}_{2}-$ eq of greenhouse gases. Therefore, it is integral to apply the proper agricultural methods to cater to the demands and needs in the cattle industry while minimizing their potential negative environmental and economic consequences.

Two interventions had been proposed by various researchers in solving this predicament. These included dietary supplementation with tannin and manipulat- ing feed energy density. Several studies suggest that supplementation of an optimum amount of tannin could result to reduce fiber digestion, decrease in ruminal gas production, increased intestinal protein, and improved growth (Naumann et al., 2017; Barajas et al., 2010). Meanwhile, manipulation of feed energy was also an effective method which also could lead to better performance, fermentation efficiency, growth performance, milk production, and lower ruminal gas emission rate for cattle (Chaokaur et al., 2015; Tangjitwattanachai \& Sommart, 2012; Alves et al., 2017b). Due to these potential advantages, the hypothesis was that tannin supplementation and appropriate energy levels could improve nutrition, growth performance, reduce ruminal gas production, and conserve resources in raising cattle, which could potentially benefit farmers. This aimed to determine the effects of tannin in the growth performance, rumen fluid characteristics, and apparent totaltract digestibility in growing Holstein-Friesian $x$ Sahiwal bulls fed low and high energy rations. 


\section{MATERIALS AND METHODS}

\section{Experimental Animals, Design, and Treatments}

A total of eighteen (18) healthy, Holstein $x$ Sahiwal crossbred growing bulls (initial body weight of $162.8 \pm 12.7 \mathrm{~kg}$ at $15 \pm 0.80$ months) from the Dairy Training and Research Institute, University of the Philippines-Los Baños were used in this study. The experimental animals were arranged in a $2 \times 2$ factorial set-up using unbalanced Randomized Complete Block Design with four to five replicate animals per treatment. The bodyweight of the experimental animal was used as the blocking factor. The four treatments were low energy concentrate without tannin (LENT), low energy concentrate with tannin (LEWT), high energy concentrate without tannin (HENT), and high energy concentrate with tannin (HEWT). Commercial tannin (Seta Sun ${ }^{\oplus}$. Seta S.A., Estancia Velha, RS, Brazil) was extracted from Acacia mearnsii bark reported to contain $72.5 \%$ total tannins ( $15 \%$ condensed and $57.5 \%$ hydrolyzable tannins). The level of tannin and metabolizable energy of the concentrate used in this study was based on the optimum recommended amount by Alves et al. (2017a) and Philippine Society of Animal Nutritionists (PHILSAN, 2010), respectively.

The animals were subjected to 14 weeks (98 days) of feeding including the 14-days adaptation period. After 14 days, the animals were weighed again when their feed intakes were stable. The forage was offered ad libitum daily with the concentrate supplemented twice a day (0800 and $1600 \mathrm{~h}$ ) at $3 \%$ of their BW on a DM basis and $75: 25$ forage to concentrate ratio. The forage was composed of available improved grasses and legumes. The growing bulls were kept in individual cages $(0.75$ $\mathrm{m} \times 1.2 \mathrm{~m}$ ) with separate feed bunk where clean water was made available at all times. The individual cages were regularly cleaned and maintained throughout the experiment.

\section{Growth Performance}

Daily feed offered and refused were recorded. Voluntary intake was estimated by the difference between the feed offered and refused. Changes in the weight of experimental bulls were monitored every 14 days. Sub-samples from forage and concentrate offered and refusal was collected and subjected to oven-drying at $70^{\circ} \mathrm{C}$ until constant weight. The sub-samples were then ground using a Wiley mill to pass through a $1 \mathrm{~mm}$ screen and stored for proximate and Van Soest fiber fraction analyses following methods of AOAC (2012) and Van Soest et al. (1991), respectively.

\section{Rumen Fluid Collection}

Approximately $200 \mathrm{~mL}$ of rumen fluid, 3 hours after morning feeding was collected from each animal using an oral rubber tube connected to a vacuum pump. The collected rumen fluid was screened using 3 layers of cheesecloth into a beaker and immediately transferred into sealed zip lock polyethylene bags. The bags were kept inside a styro-box with an internal temperature of $38-41^{\circ} \mathrm{C}$ maintained by adding warm water. After the collection and sieving, a portion of rumen fluid was preserved with 2-3 drops of toluene to prevent fermentation then it was stored at $-20^{\circ} \mathrm{C}$ temperature for the volatile fatty acid analyses.

\section{Rumen Fluid Characteristics}

Collected rumen fluid was immediately transferred to a $50 \mathrm{ml}$ syringe $\left(\right.$ Terumo ${ }^{\circledR}$ ) primarily containing 120 $\mathrm{mg}$ of cellulose microcrystalline (Avicel ${ }^{\circledR}$. Merck) as the substrate, $5 \mathrm{~mL} 0.05 \mathrm{M} \mathrm{PO}_{4}$ buffer $\mathrm{pH} 6.9$, and $1 \mathrm{~mL}$ $0.154 \mathrm{M} \mathrm{MgSO}_{4}$ to attain a final volume of $15 \mathrm{~mL}$. The plunger was pushed to make sure that no air space was present in the syringe then the mixture was sealed with para-film tapes to avoid errors. Duplicates of each sample, together with the blanks (mixture without samples) were incubated immediately in an oven at $39^{\circ} \mathrm{C}$.

Space in the syringe after the incubation period corresponds to the amount of gas produced through fermentation by rumen microbes. The gas produced was measured using the graduation of the syringe and readings were done at $3,6,12,24,48$, and $72 \mathrm{~h}$ of incubation. Data were also fitted to the model of Ørskov \& McDonald (1977) (Eq. 1) except that the parameters a, $\mathrm{b}$, and $\mathrm{c}$ were associated with gas production instead of DM degradation: $Y=a+b\left(1-e^{-c t}\right)$ wherein $Y$ was gas produced $(\mathrm{mL})$ at the time $t, a$ was gas production from the immediately soluble fraction $(\mathrm{mL}), b$ was gas production from the slowly degradable fraction $(\mathrm{mL}), a+b$ $=$ potential gas production $(\mathrm{mL}), c$ was the gas production rate constant, $e=2.71828$ (base of natural logarithm) and $t$ was the time of incubation. The fermentation kinetics was estimated using the non-linear procedure of GraphPad Prism 7.0 computer software (GraphPad Software, Inc., 2016).

For the rumen fluid volatile fatty acid analysis, the samples were prepared in the following way: $200 \mu \mathrm{l}$ of $25 \%$ ortho-phosphoric acid was added to $1 \mathrm{~mL}$ of rumen liquid (Cottyn \& Boucque, 1968). The samples were subjected to 30 minutes of centrifugation at $3000 \mathrm{rpm}$ to separate the precipitated protein. The clear supernatant was collected then concentrated methanol (3:1) was added then centrifuge again for five minutes. The solution was injected to the gas chromatography (Shimadzu GC2010 Plus) equipped with SPL-2010 Plus split/splitless injection unit, with injection volume of $1 \mu \mathrm{L}$, operated in split mode (split ratio 50:1) fitted to a flame ionization detector, using a capillary column (SH-Stabilwax-DA, $30 \mathrm{~m} \times 0.32 \mathrm{mmID} \times 0.25 \mu \mathrm{m}$, Shimadzu) with $\mathrm{N}_{2}$ as the carrier gas. As adapted from Luo et al. (2015), the flow rate was set at $1.0 \mathrm{~mL} / \mathrm{min}$., column temperature at 100 ${ }^{\circ} \mathrm{C}$ for $1 \mathrm{~min}$, increasing at a rate of $20^{\circ} \mathrm{C} / \mathrm{min}$ to 190 , then maintained for $3 \mathrm{~min}$. The temperatures for injector and detector were maintained at 220 and $250{ }^{\circ} \mathrm{C}$, respectively. Each analysis was done for $7.5 \mathrm{~min}$.

Six (6) external standard solutions were prepared before the actual analyses. These standards contained predetermined concentration of acetic acid (Univar 2789), propionic acid (Sigma-Aldrich P1386), and butyric acid (Sigma-Aldrich S55154-179). In order to 
indicate a good relationship between the measured response (area of the peak) and the acid concentrations, correlation factors $\left(\mathrm{R}^{2}>0.99\right)$ of each of the corresponding regression lines for calibration were attained first.

\section{Apparent Total-Tract digestibility}

The total fecal collection was conducted for five days. Fecal samples were frozen at $-20^{\circ} \mathrm{C}$ and stored until the end of the study. The frozen samples were thawed before drying at $60^{\circ} \mathrm{C}$ for $48 \mathrm{~h}$ and subsequently milled through a $1-\mathrm{mm}$ screen. Following milling, the daily fecal samples were composited by cow within the measurement period. Fecal samples were analyzed for the dry matter $(\mathrm{DM})$, organic matter $(\mathrm{OM})$, gross energy (GE), crude protein (CP), and neutral detergent fiber (NDF) according to the procedures of AOAC (2012) and Van Soest et al. (1991). Apparent total tract DM, OM, $\mathrm{GE}, \mathrm{CP}$, and NDF digestibility were calculated using the formulas below:

Apparent total-tract digestibility $=$

[(Nutrient Intake - Nutrient Output) / (DMI x \%

Nutrient in diet)] $\times 100 \%$

\section{Economics}

The economic analysis was based on the "feed cost per kilogram body weight gained". This was calculated in "as-fed basis" according to this formula:
Feed cost per kg BW gain= Total feed cost / Average daily gain

\section{Statistical Analysis}

All data from the growth performance parameters, nutrient intake, rumen fluid characteristics, apparent total-tract digestibility, and economics were subjected to a two-way ANOVA using PROC MIXED procedure of SAS v. 9.1 (SAS Institute, 2012). Statistical significance and tendencies were set at $p \leq 0.05$. Data with declared significant differences were subjected to mean comparison using Tukey's HSD test.

\section{RESULTS}

High energy (HE) concentrates have greater organic matter (OM), and lower ash, neutral, and acid detergent fiber which can be attributed to the greater amount of soybean meal and rice bran (Table 1). Nonetheless, low energy (LE) concentrates had greater ether extract (EE) which could be due to the inclusion of copra meal. Furthermore, concentrates with and without tannin has a relatively similar chemical composition.

No significant effect $(p>0.05)$ of tannin and energy was observed on the growth performance parameters of the animals (Table 2). Treatments only had significant interaction effect $(p=0.007)$ on the $C P$ intake. Moreover, no significant differences $(p>0.05)$ of

Table 1. Ingredients and percent nutrient composition of the concentrates and forage in dry matter basis

\begin{tabular}{|c|c|c|c|c|c|}
\hline \multirow{2}{*}{ Items } & \multirow{2}{*}{ Forage } & \multicolumn{4}{|c|}{ Concentrates } \\
\hline & & LENT & LEWT & HENT & HEWT \\
\hline \multicolumn{6}{|l|}{ Ingredients, \% } \\
\hline Wheat pollard hard & - & 39.62 & 38.83 & 20.62 & 20.21 \\
\hline Copra meal expeller & - & 35.66 & 34.95 & - & - \\
\hline Rice bran & - & 15.58 & 15.27 & 36.95 & 36.21 \\
\hline Wheat grain & - & - & - & 13.71 & 13.44 \\
\hline Soybean meal & - & - & - & 10.00 & 9.80 \\
\hline Molasses & - & 5.00 & 4.90 & 5.00 & 4.90 \\
\hline Corn grain dry rolled & - & 3.64 & 3.57 & 13.22 & 12.96 \\
\hline Salt & - & 0.30 & 0.29 & 0.30 & 0.29 \\
\hline Mineral premix & - & 0.10 & 0.10 & 0.10 & 0.10 \\
\hline Vitamin premix & - & 0.10 & 0.10 & 0.10 & 0.10 \\
\hline Tannin & - & - & 2.00 & - & 2.00 \\
\hline Total & - & 100.00 & 100.00 & 100.00 & 100.00 \\
\hline \multicolumn{6}{|l|}{ Nutrient Composition, \% } \\
\hline Dry matter & 21.08 & 90.14 & 89.73 & 89.62 & 89.53 \\
\hline Organic matter & 81.55 & 89.42 & 89.67 & 92.75 & 92.65 \\
\hline Metabolizable energy, Mcal/kg1 & 1.75 & 2.46 & 2.50 & 2.73 & 2.69 \\
\hline Total digestible nutrients & 38.63 & 77.29 & 76.99 & 81.65 & 82.71 \\
\hline Crude protein & 6.67 & 15.13 & 14.13 & 15.01 & 14.54 \\
\hline Ether extract ${ }^{2}$ & 4.54 & 6.90 & 7.38 & 4.35 & 6.18 \\
\hline Neutral detergent fiber & 66.67 & 38.46 & 40.73 & 31.81 & 28.79 \\
\hline Acid detergent fiber & 50.19 & 16.58 & 16.84 & 12.79 & 11.86 \\
\hline Ash & 18.45 & 10.58 & 10.32 & 7.25 & 7.35 \\
\hline
\end{tabular}

Note: LE=low energy; HE=high energy; NT=no tannin; WT=with tannin. 
tannin and energy were observed in the amount of total ruminal gas throughout the increasing incubation time. Nevertheless, tannin supplementation had a significant effect $(p<0.01)$ on gas production from insoluble fraction and potential gas production (Table 3). The effect of tannin and energy in the molar proportion of acetic, propionic, butyric acid, and acetic to propionic acid ratio was statistically similar ( $\mathrm{p}>0.05)$.

The supplementation of $20 \mathrm{~g} / \mathrm{kg}$ DM tannin did not affect $(p>0.05)$ the apparent total-tract digestibility of the growing bulls (Table 4). The level of dietary energy significantly affected $(p<0.05)$ only the DM and NDF digestibility. Tannin and energy had a highly sig- nificant effect $(\mathrm{p}<0.001)$ on the total feed costs (Table 5). However, the treatments had no observed significant effect $(p>0.05)$ on the feed cost per kilogram body weight gained of the growing bulls.

\section{DISCUSSION}

The level of condensed tannin (CT) used in this study was only $15 \%$ of total tannins which was equivalent to only $0.3 \% \mathrm{DM}$ of the concentrates offered. The low level of CT might be a factor in the similarity of the growth performances among NT and WT fed animals. Rivera-Mendez et al. (2017) suggested that increasing

Table 2. Growth performance and daily nutrient intake of growing Holstein-Friesian x Sahiwal bulls fed with low and high energy rations with or without dietary tannin

\begin{tabular}{|c|c|c|c|c|c|c|c|c|}
\hline \multirow{2}{*}{ Variables } & \multicolumn{4}{|c|}{ Treatments } & \multirow{2}{*}{ SEM } & \multicolumn{3}{|c|}{ p-value } \\
\hline & LENT & LEWT & HENT & HEWT & & $\mathrm{T}$ & $E$ & $\mathrm{~T} \times \mathrm{E}$ \\
\hline Initial wt., kg & 157.38 & 166.50 & 163.60 & 162.75 & 6.49 & 0.30 & 0.93 & 0.44 \\
\hline Final wt., kg & 189.50 & 204.30 & 202.80 & 207.63 & 9.05 & 0.15 & 0.22 & 0.79 \\
\hline Total body wt. gain, $\mathrm{kg}$ & 32.13 & 37.80 & 39.20 & 44.88 & 4.61 & 0.21 & 0.12 & 1.00 \\
\hline Average daily gain, $\mathrm{kg} / \mathrm{d}$ & 0.33 & 0.39 & 0.40 & 0.46 & 0.05 & 0.21 & 0.12 & 0.97 \\
\hline Feed conversion ratio & 19.23 & 16.28 & 16.04 & 13.84 & 1.93 & 0.18 & 0.15 & 0.84 \\
\hline Total DM intake, kg/d & 6.00 & 6.01 & 6.08 & 6.17 & 0.08 & 0.45 & 0.14 & 0.57 \\
\hline Forage intake & 4.50 & 4.51 & 4.56 & 4.63 & 0.06 & 0.52 & 0.13 & 0.58 \\
\hline Concentrate intake & 1.50 & 1.50 & 1.52 & 1.54 & 0.02 & 0.57 & 0.13 & 0.64 \\
\hline OM intake, kg/d & 5.13 & 5.26 & 5.24 & 5.40 & 0.07 & 0.05 & 0.08 & 0.81 \\
\hline ME intake, Mcal/d & 16.17 & 16.36 & 16.59 & 17.12 & 0.41 & 0.36 & 0.15 & 0.67 \\
\hline $\mathrm{CP}$ intake, $\mathrm{kg} / \mathrm{d}$ & $0.69^{\mathrm{ab}}$ & $0.70^{\mathrm{ab}}$ & $0.72^{\mathrm{a}}$ & $0.68^{\mathrm{b}}$ & 0.01 & 0.14 & 0.35 & 0.007 \\
\hline NDF intake, kg/d & 3.58 & 3.62 & 3.52 & 3.51 & 0.05 & 0.73 & 0.10 & 0.61 \\
\hline
\end{tabular}

Note: Means in the same row with different superscripts differ significantly $(\mathrm{p}<0.05)$; SEM= standard error of mean; LE= low energy; HE= high energy; $\mathrm{NT}=$ no tannin; $\mathrm{WT}=\mathrm{w}$ ith tannin; $\mathrm{T}=$ tannin; $\mathrm{E}=$ energy.

Table 3. Rumen fluid characteristics of growing Holstein-Friesian $x$ Sahiwal bulls fed with low and high energy rations with or without dietary tannin

\begin{tabular}{|c|c|c|c|c|c|c|c|c|}
\hline \multirow{2}{*}{ Variables } & \multicolumn{4}{|c|}{ Treatments } & \multirow{2}{*}{ SEM } & \multicolumn{3}{|c|}{$\mathrm{p}$-value } \\
\hline & LENT & LEWT & HENT & HEWT & & $\mathrm{T}$ & $E$ & $\mathrm{~T} \times \mathrm{E}$ \\
\hline \multicolumn{9}{|l|}{ Gas production, $\mathrm{mL}$} \\
\hline $3 \mathrm{~h}$ & 0.38 & 0.42 & 0.43 & 0.38 & 0.19 & 0.92 & 0.91 & 0.73 \\
\hline $6 \mathrm{~h}$ & 0.42 & 0.46 & 0.77 & 0.71 & 0.20 & 0.97 & 0.16 & 0.80 \\
\hline $12 \mathrm{~h}$ & 0.54 & 0.46 & 1.17 & 1.21 & 0.35 & 0.93 & 0.11 & 0.87 \\
\hline $24 \mathrm{~h}$ & 1.58 & 1.54 & 3.93 & 2.33 & 0.87 & 0.34 & 0.10 & 0.36 \\
\hline $48 \mathrm{~h}$ & 3.54 & 2.54 & 6.30 & 3.54 & 1.21 & 0.13 & 0.14 & 0.47 \\
\hline $72 \mathrm{~h}$ & 4.13 & 2.79 & 7.23 & 3.83 & 1.22 & 0.07 & 0.10 & 0.39 \\
\hline \multicolumn{9}{|l|}{ Fermentation kinetics ${ }^{1}$} \\
\hline $\mathrm{a}, \mathrm{mL}$ & -0.25 & -0.23 & -0.59 & -0.66 & 0.36 & 0.66 & 0.31 & 0.79 \\
\hline $\mathrm{b}, \mathrm{mL}$ & $7.21^{\mathrm{a}}$ & $3.97^{b}$ & $12.95^{\mathrm{a}}$ & $5.76^{\mathrm{b}}$ & 1.86 & 0.01 & 0.06 & 0.29 \\
\hline $\mathrm{c}, \mathrm{mL} / \mathrm{h}$ & 0.01 & 0.03 & 0.02 & 0.04 & 0.16 & 0.13 & 0.96 & 0.99 \\
\hline $\mathrm{a}+\mathrm{b}, \mathrm{mL}$ & $6.95^{\mathrm{a}}$ & $3.74^{\mathrm{b}}$ & $12.36^{\mathrm{a}}$ & $5.10^{\mathrm{b}}$ & 1.84 & 0.01 & 0.10 & 0.24 \\
\hline \multicolumn{9}{|l|}{ Volatile fatty acids, $\mathrm{mmol} / \mathrm{L}$} \\
\hline Acetic acid & 48.84 & 53.77 & 43.37 & 52.34 & 5.16 & 0.19 & 0.51 & 0.70 \\
\hline Propionic acid & 23.97 & 25.44 & 21.64 & 25.33 & 1.97 & 0.18 & 0.46 & 0.57 \\
\hline Butyric acid & 16.37 & 17.84 & 15.04 & 17.46 & 1.10 & 0.09 & 0.44 & 0.66 \\
\hline Acetic: propionic acid ratio & 2.01 & 2.11 & 2.00 & 2.05 & 0.10 & 0.49 & 0.70 & 0.80 \\
\hline
\end{tabular}

Note: Means in the same row with different superscripts differ significantly $(\mathrm{p}<0.05)$; SEM= standard error of mean; LE= low energy; HE= high energy; $\mathrm{NT}=$ no tannin; $\mathrm{WT}=\mathrm{w}$ ith tannin; $\mathrm{T}=$ tannin; $\mathrm{E}=$ energy; ${ }^{1} \mathrm{a}=$ gas production from the immediately soluble fraction (mL); $\mathrm{b}=$ gas production from the insoluble but slowly fermentable/degradable fraction $(\mathrm{mL})$; $\mathrm{c}=$ gas production rate constant $(\mathrm{mL} / \mathrm{h})$; $\mathrm{a}+\mathrm{b}=\mathrm{potential}$ gas production $(\mathrm{mL})$. 
Table 4. Apparent total-tract digestibility of growing Holstein-Friesian $x$ Sahiwal bulls fed low and high energy rations with or without dietary tannin

\begin{tabular}{|c|c|c|c|c|c|c|c|c|}
\hline \multirow{2}{*}{ \% Digestibility } & \multicolumn{4}{|c|}{ Treatments } & \multirow{2}{*}{ SEM } & \multicolumn{3}{|c|}{$\mathrm{p}$-value } \\
\hline & LENT & LEWT & HENT & HEWT & & $\mathrm{T}$ & $E$ & $\mathrm{~T} \times \mathrm{E}$ \\
\hline Dry matter & $77.34^{\mathrm{a}}$ & $76.93^{a}$ & $81.05^{b}$ & $79.77^{b}$ & 1.54 & 0.40 & 0.01 & 0.65 \\
\hline Organic matter & 71.42 & 72.03 & 75.26 & 72.29 & 1.32 & 0.39 & 0.13 & 0.17 \\
\hline Crude protein & 72.25 & 75.58 & 76.76 & 72.94 & 1.81 & 0.89 & 0.60 & 0.06 \\
\hline Gross energy & 72.61 & 73.43 & 75.68 & 73.10 & 1.21 & 0.47 & 0.26 & 0.15 \\
\hline Neutral detergent fiber & $75.26^{\mathrm{a}}$ & $75.34^{\mathrm{a}}$ & $77.10^{\mathrm{b}}$ & $77.69^{\mathrm{b}}$ & 1.31 & 0.59 & 0.02 & 0.90 \\
\hline
\end{tabular}

Note: Means in the same row with different superscripts differ significantly $(\mathrm{p}<0.05)$; $\mathrm{SEM}=$ standard error of mean; LE= low energy; HE= high energy; $\mathrm{NT}=$ no tannin; WT=w ith tannin; $\mathrm{T}=$ tannin; $\mathrm{E}=$ energy.

Table 5. Economic analyses of growing Holstein-Friesian $x$ Sahiwal bulls fed low and high energy rations with or without dietary tannin (as-fed basis)

\begin{tabular}{|c|c|c|c|c|c|c|c|c|}
\hline \multirow{2}{*}{ Costs, US $\$ / \mathrm{kg}$} & \multicolumn{4}{|c|}{ Treatments } & \multirow{2}{*}{ SEM } & \multicolumn{3}{|c|}{ p-value } \\
\hline & LENT & LEWT & HENT & HEWT & & $\mathrm{T}$ & $\mathrm{E}$ & $\mathrm{T} \times \mathrm{E}$ \\
\hline Concentrate cost & 0.26 & 0.31 & 0.30 & 0.35 & - & - & - & - \\
\hline Total feed cost & $64.70^{c}$ & $74.11^{\mathrm{b}}$ & $71.61^{\mathrm{b}}$ & $82.24^{\mathrm{a}}$ & 1.08 & $<0.001$ & $<0.001$ & 0.16 \\
\hline Feed cost $/ \mathrm{kg}$ gain in wt. & 2.12 & 2.03 & 1.94 & 1.90 & 0.23 & 0.76 & 0.50 & 0.93 \\
\hline
\end{tabular}

Note: Means in the same row with different superscripts differ significantly $(\mathrm{p}<0.05)$; SEM= standard error of mean; LE= low energy; HE= high energy; $\mathrm{NT}=$ no tannin; WT=w ith tannin; $\mathrm{T}=$ tannin; $\mathrm{E}=$ energy.

CT level up to $0.6 \%$ could increase the performance of cattle. It was known that tannin supplementation in copious amounts could negatively affect the palatability of the feeds due to its astringent taste thereby reducing DMI (Waghorn, 2008). In the current study, supplementation of $20 \mathrm{~g} / \mathrm{kg}$ tannin had no negative impact on the DMI and performance of cattle which corresponded to the recommendation of Alves et al. (2017a). Huang et al. (2018) suggested that the potential of tannin in improving growth performance depends on its source, chemical compositions, and structure.

The similarity in the growth performance of LE and HE fed animals could be ascribed to their non-significant differences in the metabolizable energy intake (MEI) (Table 2). The similarity in the MEI ascertained that LE fed animals tried to compensate their energy requirements by increasing and leveling their DMI with the HE fed animals. Another factor could be that high energy feeds could increase internal body temperature (Cho et al., 2014) which was aggravated by the fact that the current study was conducted during the hot tropical season. These factors may have resulted in the limiting of DMI and growth of HE-fed animals in order to avoid heat-stress.

Tannin supplementation tended to increase the OM intake. This finding was not in agreement with studies which mentioned that tannin at relatively low amount either have no effect (Dallastra et al., 2018) or could reduce OM intake (Kozloski et al., 2012). The mechanism that resulted to the enhanced $\mathrm{OM}$ intake of tannin supplemented animals was uncertain due to the absence of study utilizing particularly Seta-Sun tannin and its effect on cattle performance.

The significant interaction between tannin and energy were only observed in the crude protein intake (CPI) of the growing bulls. The addition of dietary tannin in the HE concentrates resulted in the reduction of
CPI compared to animals fed with HENT. Meanwhile, CPI of animals fed with LENT and LEWT were the same. The differences in the ingredients of the LE and HE concentrates might have affected the size, structure, and the other attributes of protein present in the concentrates. Jeronimo et al. (2016) mentioned that size and structure of protein might affect its protein-binding capacity with tannins.

Koenig et al. (2018) stated that adding 25g/kg DM tannin in the diet of beef feedlot cattle fed with distiller's grain had no effect on the total VFA concentration, acetate, propionate, and acetate to propionate ratio. Koenig et al. (2018) also utilized tannin from Black wattle (Acacia mearnsii); however, the tannin extract used in their study has $38 \%$ greater amount of condensed tannin. The source and concentration of tannin may have a varying effect on its effectivity in altering VFA production. Furthermore, the level of energy did not affect the rumen volatile fatty acid production of the growing bulls. This was in good agreement with studies that stated that low and high energy diets had no effect on the ruminal VFA content of finishing steers (Navarette et al., 2017) and (Cho et al., 2014) in Hanwoo steers.

The volume of gas production increased with the increasing time of incubation suggesting the continuous fermentation process in the syringes. It is speculated that the potential of rumen microbes to produce gases from cellulose was reduced by $46 \%$ and $58 \%$ in LEWT and HEWT, respectively. This scenario could be attributed to the lower population and reduced fermenting ability of the rumen microbes. Gemeda \& Hassen (2015) cited that tannin has bactericidal and bacteriostatic effects on the rumen microbes and could inhibit their enzymatic actions, which eventually results in suppressed fermentation. Tannins form complexes with protein and polysaccharides that decrease the digestibility of dry and organic matter thus reducing metabolic $\mathrm{H}_{2}$ pro- 
duction. The decline of $\mathrm{H}_{2}$ means a lesser substrate for methanogens to reduce $\mathrm{CO}_{2}$ to $\mathrm{CH}_{4}$ thus, reducing gas production (Pineiro-Vasquez et al., 2015).

Supplementation of tannin could reduce ruminal degradation of OM, DM, NDF, and protein (Avila et al., 2015; Kozloski et al., 2012) thereby, increasing nutrient availability in the duodenum. It was well known that tannin could form complexes with protein, but it can also interfere with DM, OM, and NDF digestions. High doses of tannin are reported to decrease digestibility (Frutos et al., 2004) and it could also negatively affect the action of digestive enzymes such as amylase, lipase, and glucosidase (Ikarashi et al., 2010). Nevertheless, tannin did not affect $(p>0.05)$ the apparent total-tract digestibility. This suggested that supplementing of tannin at a dose of $20 \mathrm{~g} / \mathrm{kg}$ DM was not enough to cause any alteration in the apparent total-tract digestibility. Therefore, supplementing of tannin at a dose of $20 \mathrm{~g} / \mathrm{kg}$ DM could be set as an optimum amount to prevent any adverse effect on the apparent total-tract digestibility.

Growing dairy bulls fed with HE had greater DM and NDF digestibility than bulls fed with LE. This finding contradicts the claim by Tangjitwattanachai \& Sommart (2012) that increasing ME level cannot improve apparent total-tract digestibility. The increase in the DM digestibility of animals fed with HE was corroborated by Navarette et al. (2017). The DMI was similar across growing bulls fed with LE and HE (Table 2). This confirms that the differences in the DM digestibility were not affected by the intake but rather by the ability of the rumen microorganisms to digest DM.

The greater NDF digestibility of growing bulls fed with HE could be attributed to the lower NDF content of the HE concentrates (Table 1). Smaller fiber fraction of the feed provides a faster turnover rate and can be digested faster in the rumen thus. These fiber fractions can be converted more easily into a soluble form and be absorbed in the gastrointestinal tract. This finding agreed to the study of Navarette et al. (2017), wherein they found out that NDF digestibility was also greater with finishing steer fed with high energy diets.

The addition of an external source of tannin in the concentrates increased the total feed cost due to its US\$ 3.38/kg additional cost. Furthermore, addition of soybean meal and higher amount of rice bran $D_{1}$ in the concentrates also increased the total feed costs. The former is known for commanding a higher price (US\$ 0.48/ $\mathrm{kg}$ ), as being imported and because of its high energy and protein contents. Meanwhile, the latter was added in the formulation twice as much compared to the low energy concentrates on achieving the high energy level of the concentrates. Feeding low energy without tannin to growing bulls incurred feed savings costs up to US\$ 17.59. Therefore, increasing feed energy and supplementing tannin at dose of $20 \mathrm{~g} / \mathrm{kg}$ DM augmented the total feed cost without improving the growth performance.

\section{CONCLUSION}

Dietary tannin and feed energy levels have no effect in improving growth performance and rumen volatile fatty acids. Tannin and energy only had interaction effect on the CP intake. Moreover, tannin supplementation had a tendency to reduce rumen gas production. Increasing the energy of the diet improved only DM and NDF digestibilities. Increasing energy of the feed and inclusion of $20 \mathrm{~g} / \mathrm{kg}$ tannin would only incur additional feed cost without improving growth performance. Further researches must emphasize assessing the optimum concentration of tannin and appropriate energy levels that would improve productivity and increase the economic viability of raising growing cattle.

\section{CONFLICT OF INTEREST}

We certify that there is no conflict of interest with any financial, personal, or other relationship with other people or organizations related to the material discussed in the manuscript.

\section{ACKNOWLEDGEMENT}

The authors wish to acknowledge the financial support provided by the Department of Science and Technology - Accelerated Science and TechnologyHuman Resource and Development Program (DOSTASTHRDP) and the Philippine Council for Agriculture, Aquatic, and Natural Resources Research and Development (PCAARRD). The authors also gratefully acknowledge the Dairy Training and Research Institute (DTRI) for the animals used in this study.

\section{REFERENCES}

Alves, T. P., A. C. Dall-Orsoletta \& H. M. Ribeiro-Filho. 2017a. The effects of supplementing Acacia mearnsii tannin extract on dairy cow dry matter intake, milk production, and methane emission in a tropical pasture. Trop. Anim. Health Prod. 49:1663-1668. https://doi.org/10.1007/ s11250-017-1374-9

Alves, T. P., K. M. Dias, L. J. Dallastra, B. L. Fonseca \& H. M. Ribeiro-Filho. 2017b. Energy and tannin extract supplementation for dairy cows on annual winter pastures. Semina:Ciencias Agrarias 38: 1017-1026. https://doi. org/10.5433/1679-0359.2017v38n2p1017

AOAC. 2012. Official Methods of Analysis of AOAC International. 18th ed. Assoc. Off. Anal. Chem., Arlington.

Avila, S. C., G. V. Kozloski, T. Orlandi, M. P. Mezzomo, \& S. Stefanello. 2015. Impact of a tannin extract on digestibility, ruminal fermentation and duodenal flow of amino acids in steers fed maize silage and concentrate containing soybean meal or canola meal as protein source. J. Agr. Sci. 153:943-953. https://doi.org/10.1017/S0021859615000064

Barajas, R., B. J. Cervantes, A. Camacho, E. A. Velázquez, M. A. Espino, F. Juárez, L. R. Flores, \& M. Verdugo. 2010. Condensed tannins supplementation on feedlot performance of growing bulls. Proceedings of Western Section American Society of Animal Science 61:209-11.

Chaokaur, A., T. T. Nishida, I. Phaowphaisal \& K. Sommart. 2015 Effects of feeding level on methane emissions and energy utilization of Brahman cattle in the tropics. Agriculture, Ecosystems, and Environment. 199:225-230. https://doi.org/10.1016/j.agee.2014.09.014

Cho, S., D. T. Mbiriri, K. Shim, A. L. Lee, S. J. Oh, J. Yang, C. Ryu, Y. H. Kim, K. S. Seo, J. I. Chae, Y. K. Oh \& N. J. Choi. 2014. The influence of feed energy density and 
a formulated additive on rumen and rectal temperature in Hanwoo steers. Asian-Australas. J. Anim. Sci. 27:16521662. https://doi.org/10.5713/ajas.2014.14562

Cottyn, B. G. \& C. H. Boucque. 1968. Rapid method for the gas chromatographic determination of volatile fatty acids in rumen fluid. J. Agric. Food Chem. 16:105-107. https://doi. org/10.1021/jf60155a002

Dallastra, L. J. H., T. P. Alves, J. G. Dal-Pizzol, B. L. Fonseca, M. Camera, G. T. Raupp \& H. M. Ribeiro-Filho. 2018. Tannin extract of Acacia mearnsii for lactating ewes. Semina: Ciencias Agrarias 39: 2741-2748. https://doi. org/10.5433/1679-0359.2018v39n6p2741

FAO (Food and Agriculture Organization of the United Nations). 2016. FAOSTAT Database. Rome, Italy: FAO. Retrieved April 1, 2019 from http://www.fao.org/ faostat/en/\#data/QA/visualize.

FAO (Food and Agriculture Organization of the United Nations). 2017. Global Livestock Environmental Assessment Model (GLEAM). Rome, Italy: FAO. Retrieved August 22, 2019 from http://www.fao.org/gleam/results/ en/.

Frutos, P., G. Hervás, F. J. Giráldez, \& A. R. Mantecón. 2004. Review. tannins and ruminant nutrition. Span. J. Agric. Res. 2:191-202. https://doi.org/10.5424/sjar/2004022-73

Gemeda, B. S. \& A. Hassen. 2015. Effect of tannin and species variation on in vitro digestibility, gas, and methane production of tropical browse plants. Asian Australas. J. Anim. Sci. 28:188-199. https://doi.org/10.5713/ajas.14.0325

Graphpad Software, Inc. 2016. Graphpad Prism v. 7. [Computer software]. San Diego CA.

Huang, Q., X. Liu, G. Zhao, T. Hu, \& Y. Wang. 2018. Potential and challenges of tannins as an alternative to in-feed antibiotics for farm animal production. Anim. Nutr. 4:137-150. https://doi.org/10.1016/j.aninu.2017.09.004

Ikarashi, N., R. Takeda, K. Ito, W. Ochiai \& K. Sugiyama. 2011. The inhibition of lipase and glucosidase activities by Acacia polyphenol. Evidence-Based Complementary and Alternative Medicine vol. 2011, Article ID 272075, 8 pages, 2011. https://doi.org/10.1093/ecam/neq043

Jeronimo, E., C. Pinheiro, E. Lamy, M. T. Dentino, E. SalesBaptista, O. Lopes \& F. C. Silva. 2016. Tannins in Ruminant Nutrition: Impact on Animal Performance and Quality of Edible Products. In: C.A. Combs (Ed). Tannins: Biochemistry, Food Sources and Nutritional Properties. Nova Science Publishers Inc., New York. p. 1-43.

Koenig, K. M., K. A. Beauchemin \& S. M. Mcginn. 2018. Feeding condensed tannins to mitigate ammonia emissions from beef feedlot cattle fed high-protein finishing diets containing distillers grains. J. Anim. Sci. 96:4414-4430. https://doi.org/10.1093/jas/sky274

Kozloski, G. V., C. J. Harter, F. Hentz, S. Capa De Avila, T. Orlandi \& C. M. Stefanello. 2012. Intake, digestibility and nutrients supply to wethers fed ryegrass and intraruminally infused with levels of Acacia mearnsii tannin extract. Small Rumin. Res. 106:125-130. https://doi.org/10.1016/j. smallrumres.2012.06.005
Luo, C., S. Cai, L. Jia, X. Tang, R. Zhang, G. Jia, H. Li, J. Tang, G. Liu \& C. Wu. 2015. Study on accurate determination of volatile fatty acids in rumen fluid by capillary gas chromatography. $5^{\text {th }}$ International Conference on Information Engineering for Mechanics and Materials (ICIMM 2015). Atlantis Press, China. Pp. 386-391. https://doi.org/10.2991/ icimm-15.2015.73

Naumann, H. D., Tedeschi, L. O., Zeller, W. E., \& Huntley, N. F. 2017. The role of condensed tannins in ruminant animal production: advances, limitations and future directions. R. Bras. Zootec. 46:929-949. https://doi.org/10.1590/ s1806-92902017001200009

National Research Council. 2001. Nutrient Requirements of Dairy Cattle. 7th rev. ed. Natl. Acad. Sci., Washington, DC.

Navarrete, J. D., M. F. Montano, C. Raymundo, J. SalinasChavira, N. Torrentera \& R. A. Zinn. 2017. Effect of energy density and virginiamycin supplementation in diets on growth performance and digestive function of finishing steers. Asian-Australas. J. Anim. Sci. 30(10):1396-1404. https://doi.org/10.5713/ajas.16.0826

Ørskov, E. R. \& P. McDonald. 1979. The estimation of protein degradability in the rumen from incubation measurements weighed according to rate of passage. J. Agri. Sci. 92: 499-503. https://doi.org/10.1017/S0021859600063048

Philippine Society of Animal Nutritionists (PHILSAN). 2010. PHILSAN Feed Reference Standards. 4th ed. University of the Philippines-Los Baños, Laguna, Philippines. p. 163.

Piñeiro-Vazquez, A. T., J. R. Canul-Solís, J. A. Alayón-Gamboa, A. J. Chay-Canul, A. J. Ayala-Burgos, C. F. Aguilar-Pérez, F. J. Solorio-Sánchez \& J. C. Ku-Vera. 2015. Potential of condensed tannin for the reduction of emission of enteric methane and their effect on ruminant productivity. Arch. Med. Vet. 47: 263-272. https://doi.org/10.4067/ S0301-732X2015000300002

Rivera-Mendez, C. R., A. Plascencia, N. Torrentera \& R. A. Zinn. 2017. Effect of level and source of supplemental tannin on growth performance of steers during the late finishing phase. J. Appl. Anim. Res. 45: 199-203. https://doi.org/ 10.1080/09712119.2016.1141776

SAS Institute. 2012. SAS User's Guide: Statistics (Version. 9.1 ed.), SAS Inst. Inc., Cary, NC.

Tangjitwattanachai N. \& K. Sommart. 2012. Effects of metabolizable energy intake on growth performance and nutrient digestibility of Thai native cattle. Khon Kaen Agricultural Journal 40:536-540.

Van Soest, P. J., J. B. Robertson \& B. A. Lewis. 1991. Methods for dietary fiber, neutral detergent fiber, and nonstarch polysaccharides in relation to animal nutrition. J. Dairy Sci. 74:3583-3597. https://doi.org/10.3168/jds. S0022-0302(91)78551-2

Waghorn, G. 2008. Beneficial and detrimental effects of dietary condensed tannins for sustainable sheep and goat production-Progress and challenges. Anim. Feed Sci. Tech. 147:116139. https://doi.org/10.1016/j.anifeedsci.2007.09.013 